\title{
Dukungan Keluarga Dan Perilaku Penderita Hipertensi Terhadap Pencegahan Stroke
}

\author{
Auwalia Noer Cahyanti ${ }^{1}$, Ns. Destiawan Eko Utomo, M. Kep., Sp. Kep. MB ${ }^{2}$ \\ ${ }^{1}$ Mahasiswi Program S1 Keperawatan, STIKes Yatsi Tangerang 15113, Indonesia \\ ${ }^{2}$ Dosen Keperawatan, STIKes Yatsi Tangerang 15113, Indonesia \\ Email : auwalianoercahyanti@gmail.com
}

Tanggal submisi: 4 September 2020; Tanggal penerimaan: 7 Desember 2020

\begin{abstract}
ABSTRAK
Latar belakang: Hipertensi merupakan masalah kesehatan dengan peningkatan tekanan darah $\geq 140 / 90 \mathrm{mmHg}$. Dukungan keluarga sangat penting bagi penderita hipertensi sehingga penderita lebih patuh dalam menjalani pengobatannya dan mencegah terjadinya stroke. Tujuan: Untuk mengetahui seberapa pentingnya dukungan keluarga dan perilaku penderita hipertensi terhadap pencegahan stroke. Metode: Rentang tahun 2015-2020 dengan menggunakan Google Scholar, Research Gate, Semantic Scholar, Elsevier, Portal Garuda dan Mendeley. Hasil: Dari 35 artikel yang sesuai dengan topik dan tujuan penelitian didapatkan sebanyak 17 artikel yang menunjukkan adanya hubungan antara dukungan keluarga dan perilaku hipertensi dalam pencegahan stroke dengan nilai $p$ value $(<0,05)$ dan sesuai dengan kriteria inklusi dan eksklusi. Kesimpulan: Didapatkan yang memiliki dukungan keluarga dalam kategori sedang hingga tinggi. Tetapi di berbagai literatur terdapat perilaku penderita hipertensi dalam pencegahan stroke masuk kategori kurang hingga cukup. Tingginya dukungan dari keluarga sangat diharapkan untuk mengelola perilaku penderita hipertensi dalam pencegahan stroke. Meningkatkan kesadaran diri penderita hipertensi juga sangat berpengaruh untuk dapat melaksanakan perawatan diri dengan baik dalam mencegah komplikasi pada penderita hipertensi.
\end{abstract}

Kata Kunci : Dukungan Keluarga Hipertensi, Perilaku Hipertensi, Pencegahan Stroke Pada Hipertensi

\begin{abstract}
Background: Hypertension is a health problem with an increase in blood pressure $\geq$ $140 / 90 \mathrm{mmHg}$. Family support is very important for people with hypertension so that patients are more obedient in undergoing treatment and preventing stroke. Objective: To determine the importance of family support and behavior of hypertensive sufferers for stroke prevention. Methods: 2015-2020 spanning using Google Scholar, Research Gate, Semantic Scholar, Elsevier, Portal Garuda and Mendeley. Results: Of the 35 articles that fit the topic and purpose of the study, 17 articles showed a relationship between family support and hypertensive behavior in stroke prevention with a $p$ value $(<0.05)$ and according to the inclusion and exclusion criteria. Conclusion: There are those who have family support in the moderate to high category. However, in various literatures, the behavior of hypertension sufferers in preventing stroke is in the category of insufficient to sufficient. High support from families is expected to manage the behavior of hypertension sufferers in preventing stroke. Increasing self-awareness of hypertension sufferers is also
\end{abstract}


very influential in being able to carry out self-care properly in preventing complications in people with hypertension.

Keywords : Family Support for Hypertension, Hypertensive Behavior, Prevention of Stroke in Hypertension

ISSN 1979-7621 (Print). ISSN 2620-7761 (Online).

DOI : $10.23917 / j k . v 14 i 1.9215$

\section{PENDAHULUAN}

Hipertensi merupakan masalah dalam kesehatan yang dicirikan dengan peningkatan tekanan darah $\geq 140 / 90 \mathrm{mmHg}$ (Bisnu, 2017).

Di dunia yang memiliki hipertensi tertinggi hampir 1 milyar orang dengan tekanan darah sistolik $\geq 140 \mathrm{mmHg}$ dan tekanan darah diastolik $\geq 90 \mathrm{mmHg}$, dan dari dua pertiga diantaranya berada di negara berkembang yang berpenghasilan rendah hingga sedang (Andri, 2018)

Prevalensi hipertensi di Indonesia yang di dapat berdasarkan hasil pengukuran penduduk umur $\geq 18$ sebesar $44,1 \%$ pada tahun 2018. Dari hasil pengukuran ke penduduk dengan umur lebih dari sama dengan 18 tahun pada provinsi banten sebesar 29,47\% (Amelia, 2020; Riskesdas, 2018).

Tujuan dukungan keluarga pada penderita hipertensi agar kondisi yang dialami tidak semakin memburuk dan terhindar dari komplikasi akibat hipertensi. Keluarga bisa membantu dalam mengatur pola makan yang sehat, mengajak olahraga bersama, menemani dan mengingatkan rutin untuk memeriksakan tekanan darahnya (Bisnu et al, 2017).

Perilaku penderita hipertensi yang baik yaitu dengan adanya perubahan perilaku sehat seperti latihan menjaga diet, berhenti mengkonsumsi alkohol dan merokok, serta mengurangi mengkonsumsi garam (Adriani, 2018).

Upaya pencegahan stroke adalah upaya-upaya yang dilakukan oleh penderita hipertensi dalam melakukan upaya agar terhindar dari stroke serta dapat melakukan pencegahan dengan baik. (Jumarni et al, 2015).

Tujuan dari literature review untuk mengetahui seberapa besar pentingnya dukungan keluarga dan perilaku penderita hipertensi terhadap pencegahan stroke.

\section{METODE}

Studi literatur ini diperoleh dari artikel-artikel penelitian dari rentang tahun 2015 - 2020 dengan menggunakan sumber dari Google Scholar, Research Gate, Semantic Scholar, Elsevier, Portal Garuda dan Mendeley dengan total awal pencarian yaitu sebanyak 35 artikel.

Pada literature review ini data awal pencarian yang didapat dari Google Scholar sebanyak 9 artikel dan yang dipilih sesuai dengan topik dan tujuan penelitian sebanyak 4 artikel. Data awal pencarian yang didapat dari Research Gate sebanyak 10 artikel dan yang dipilih sebanyak 8 artikel, data awal pencarian yang didapat dari Elsevier sebanyak 3 artikel dan yang dipilih sebanyak 1 artikel, data awal pencarian yang didapat dari Portal Garuda sebanyak 1 artikel dan yang dipilih sebanyak 1 artikel, data awal pencarian yang didapat dari Semantic Scholar sebanyak 1 artikel dan yang dipilih sebanyak 1 artikel, sedangkan data awal pencarian yang didapat dari Mendeley sebanyak 11 artikel dan yang dipilih sebanyak 2 artikel. 
Tabel 1.1 Kriteria Inklusi dan Eksklusi

\begin{tabular}{|c|c|}
\hline Kriteria Inklusi & Kriteria Eksklusi \\
\hline $\begin{array}{l}\text { Responden penderita } \\
\text { hipertensi }\end{array}$ & $\begin{array}{l}\text { Responden masyarakat, } \\
\text { pasien stroke pada hipertensi }\end{array}$ \\
\hline $\begin{array}{l}\text { Dapat diakses full text } \\
\text { dalam format pdf }\end{array}$ & $\begin{array}{l}\text { Artikel hanya abstrak atau } \\
\text { review artikel }\end{array}$ \\
\hline $\begin{array}{l}\text { Jurnal terpublish secara } \\
\text { resmi }\end{array}$ & $\begin{array}{l}\text { Jurnal tidak terpublish secara } \\
\text { resmi }\end{array}$ \\
\hline $\begin{array}{l}\text { Bahasa Indonesia dan } \\
\text { Bahasa Inggris }\end{array}$ & $\begin{array}{l}\text { Bahasa China dan bahasa } \\
\text { asing lainnya. }\end{array}$ \\
\hline Tahun 2015 - Tahun 2020 & Tahun 2014 ke bawah \\
\hline $\begin{array}{l}\text { Adanya dukungan dari } \\
\text { keluarga dalam perilaku } \\
\text { pencegahan stroke }\end{array}$ & $\begin{array}{l}\text { Adanya dukungan } \\
\text { masyarakat dan } \\
\text { kesehatan }\end{array}$ \\
\hline
\end{tabular}

Tabel 1.2 Komponen PICOT

\begin{tabular}{|c|c|c|}
\hline Komponen & Pedoman & Permasalahan \\
\hline Population & $\begin{array}{c}\text { Populasi yang akan dianalisis sesuai dengan } \\
\text { topik yang sudah ditentukan }\end{array}$ & $\begin{array}{c}\text { Responden penderita } \\
\text { hipertensi }\end{array}$ \\
\hline Intervention & $\begin{array}{c}\text { Tindakan penatalaksanaan sesuai dengan } \\
\text { topik yang sudah ditentukan }\end{array}$ & Tidak Ada \\
\hline Comparation & $\begin{array}{c}\text { Penatalaksanaan lain yang digunakan sebagai } \\
\text { pembanding }\end{array}$ & Tidak Ada \\
\hline Outcomes & $\begin{array}{c}\text { Hasil yang diperoleh pada studi terdahulu } \\
\text { yang sesuai dengan topik yang sudah } \\
\text { ditentukan }\end{array}$ & $\begin{array}{c}\text { Adanya dukungan } \\
\text { keluarga dalam perilaku } \\
\text { pencegahan stroke }\end{array}$ \\
\hline Time & Waktu yang diperlukan untuk pengambilan \\
data responden & $\begin{array}{c}\text { 1 bulan, 2 bulan, 3 bulan, } \\
\text { 4 bulan }\end{array}$ \\
\hline
\end{tabular}




\section{HASIL DAN PEMBAHASAN}

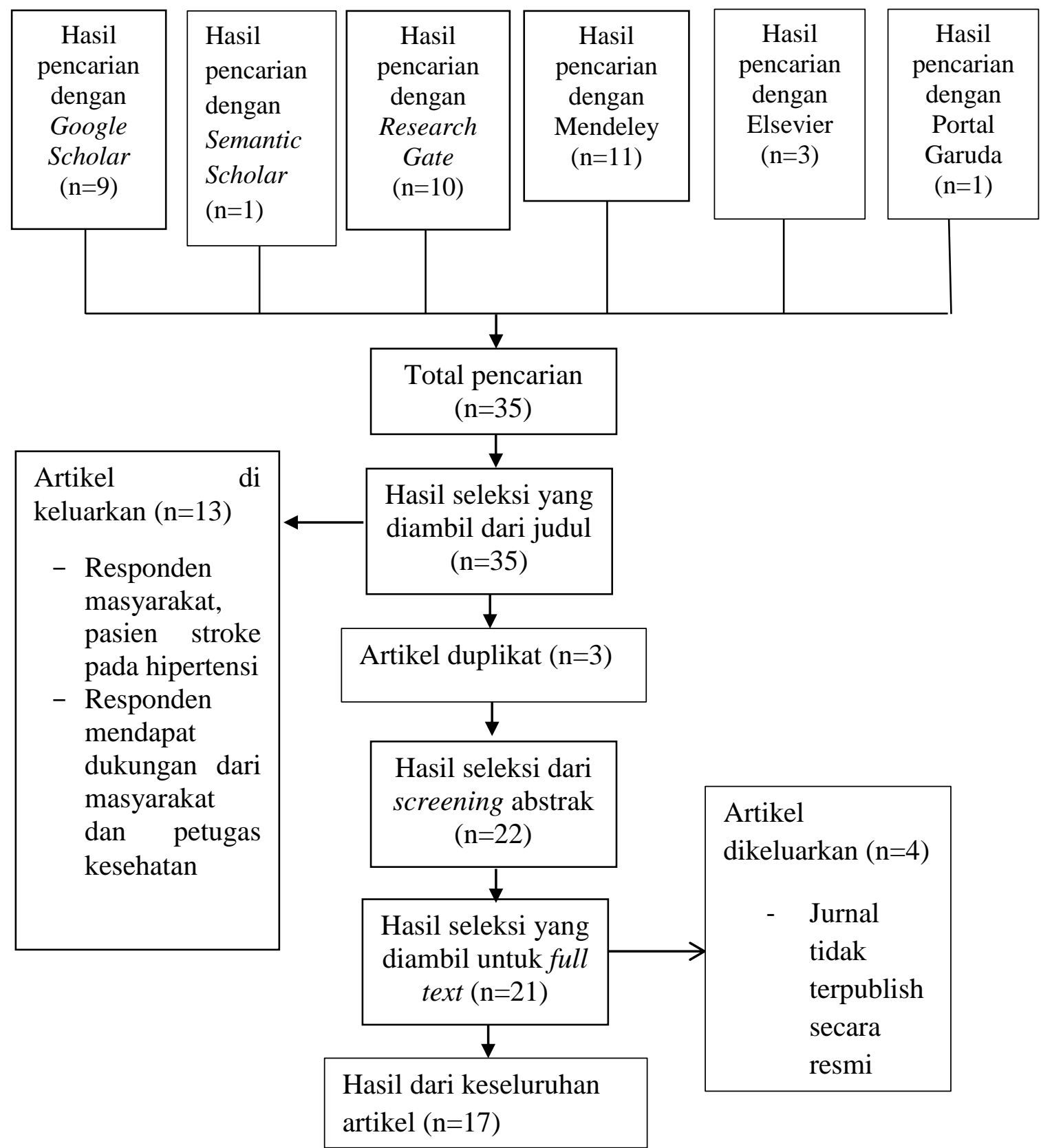

Bagan 1.1 Modifikasi Flow Diagram (Moher et al., 2009) 


\begin{tabular}{|c|c|c|c|c|c|c|}
\hline No & Peneliti & Sampel & Metode & Judul & Sumber & Hasil / Kesimpulan \\
\hline 1. & $\begin{array}{l}\text { Fitra } \\
\text { Yeni, } \\
\text { Miftahu } \\
1 \\
\text { Husna, } \\
\text { Dachriy } \\
\text { anus }\end{array}$ & $\begin{array}{l}59 \\
\text { orang }\end{array}$ & $\begin{array}{l}\text { Deskriptif- } \\
\text { korelatif } \\
\text { dengan } \\
\text { metode } \\
\text { penelitian } \\
\text { cross- } \\
\text { sectional }\end{array}$ & $\begin{array}{l}\text { Dukungan } \\
\text { Keluarga } \\
\text { Memengaruh } \\
\text { i Kepatuhan } \\
\text { Pasien } \\
\text { Hipertensi }\end{array}$ & $\begin{array}{l}\text { Jurnal } \\
\text { Keperawatan } \\
\text { Indonesia, } \\
\text { Volume } \\
\text { No.3, } \\
\text { November } \\
2016 \text {, hal } 137- \\
144 \\
\text { pISSN 1410- } \\
4490, \quad \text { ISSN } \\
2354-9203 \\
\end{array}$ & $\begin{array}{l}\text { Adanya hubungan antara } \\
\text { kepatuhan pasien dengan } \\
\text { dukungan keluarga dengan } \\
\text { uji rank spearmen yaitu } \\
\text { nilai }(\mathrm{r})=0,786 \text { dengan } \\
\text { nilai p value dukungan } \\
\text { keluarga }(0,000) \text { dan nilai } \mathrm{p} \\
\text { value kepatuhan }(0,001) \text {. }\end{array}$ \\
\hline 2. & $\begin{array}{l}\text { Oluwas } \\
\text { eun S. } \\
\text { Ojo, } \\
\text { Sunday } \\
\text { O. } \\
\text { Malom } \\
\text { o, } \\
\text { Peter T. } \\
\text { Sogunl } \\
\text { e }\end{array}$ & $\begin{array}{l}360 \\
\text { respond } \\
\text { en }\end{array}$ & $\begin{array}{l}\text { Cross } \\
\text { Sectional } \\
\text { dan } \\
\text { menggunak } \\
\text { an uji chi } \\
\text { square. }\end{array}$ & $\begin{array}{l}\text { Blood } \\
\text { pressure (BP) } \\
\text { Control and } \\
\text { Perceived } \\
\text { Family } \\
\text { Support in } \\
\text { Patients with } \\
\text { Essential } \\
\text { Hypertension } \\
\text { Seen at a } \\
\text { Primary Care } \\
\text { Clinic in } \\
\text { Western } \\
\text { Nigeria }\end{array}$ & $\begin{array}{l}\text { Journal of } \\
\text { Family } \\
\text { Medicine and } \\
\text { Primary } \\
2016\end{array}$ & $\begin{array}{l}\text { Responden yang memiliki } \\
\text { dukungan keluarga yang } \\
\text { kuat sekitar lima kali lebih } \\
\text { mampu untuk } \\
\text { mengendalikan tekanan } \\
\text { darah dari pada responden } \\
\text { yang tidak memiliki } \\
\text { dukungan keluarga kuat (P } \\
=0.000, \mathrm{OR}=4.778) \text {. }\end{array}$ \\
\hline 3. & $\begin{array}{l}\text { Aszrul } \\
\text { AB } \\
\text { Andi } \\
\text { Suswan } \\
\text { i }\end{array}$ & $\begin{array}{l}50 \\
\text { respond } \\
\text { en }\end{array}$ & $\begin{array}{l}\text { Desain } \\
\text { observasion } \\
\text { al analitik } \\
\text { dengan } \\
\text { pendekatan } \\
\text { case } \\
\text { control. } \\
\text { Analisa data } \\
\text { menggunak } \\
\text { an uji chi } \\
\text { square. }\end{array}$ & $\begin{array}{l}\text { Dukungan } \\
\text { Keluarga } \\
\text { dengan } \\
\text { Upaya } \\
\text { Meminimalis } \\
\text { ir } \\
\text { Serangan } \\
\text { Stroke } \\
\text { Penderita } \\
\text { Hipertensi di } \\
\text { Wilayah } \\
\text { Kerja } \\
\text { Puskesmas } \\
\text { Bontonyelen } \\
\text { g } \\
\text { Kecamatan } \\
\text { Gattareng }\end{array}$ & $\begin{array}{l}\text { Jurnal } \\
\text { Kesehatan } \\
\text { Panrita Husada } \\
\text { | Vol. } 2 \text { No.1, } \\
\text { Maret } 2017\end{array}$ & $\begin{array}{l}\text { Nilai p value } 0,000 \text { (p < } \\
0,05) \text { yang artinya adanya } \\
\text { hubungan dukungan } \\
\text { keluarga dengan upaya } \\
\text { meminimalisir serangan } \\
\text { stroke di wilayah tersebut. }\end{array}$ \\
\hline 4. & $\begin{array}{l}\text { Tyas } \\
\text { Dwi } \\
\text { Widian } \\
\text { dari, } \\
\text { Esti }\end{array}$ & $\begin{array}{l}46 \\
\text { orang }\end{array}$ & $\begin{array}{l}\text { Analitik } \\
\text { korelasi } \\
\text { dengan } \\
\text { pendekatan } \\
\text { cross } \\
\end{array}$ & $\begin{array}{l}\text { Hubungan } \\
\text { Dukungan } \\
\text { Keluarga } \\
\text { terhadap } \\
\text { Motivasi } \\
\end{array}$ & $\begin{array}{lr}\text { Nursing } & \text { News } \\
\text { Volume } & 3 \text {, } \\
\text { Nomor } 1,2018\end{array}$ & $\begin{array}{l}\text { Hasil nilai } \alpha=0,000 \text { maka } \\
\text { H1 diterima karna }<0,05 \\
\text { dan dapat disimpulkan } \\
\text { adanya hubungan antara } \\
\text { dukungan keluarga dengan }\end{array}$ \\
\hline
\end{tabular}




\begin{tabular}{|c|c|c|c|c|c|c|}
\hline & $\begin{array}{l}\text { Widiani } \\
\text {, Yanti } \\
\text { Rosdia } \\
\text { na }\end{array}$ & & sectional. & $\begin{array}{l}\text { Lansia Dalam } \\
\text { Pengelolaan } \\
\text { Penyakit } \\
\text { Hipertensi di } \\
\text { Poli Interna } \\
\text { Rst Dr. } \\
\text { Soepraoen } \\
\text { Malang }\end{array}$ & & $\begin{array}{l}\text { motivasi lansia dalam } \\
\text { pengelolaan hipertensi. }\end{array}$ \\
\hline 5. & $\begin{array}{l}\text { Ria } \\
\text { Mislin } \\
\text { Asmiart } \\
\text { i, } \\
\text { Farida } \\
\text { Hayati, } \\
\text { Linda } \\
\text { Isharian } \\
\text { i }\end{array}$ & $\begin{array}{l}41 \\
\text { Respon } \\
\text { den }\end{array}$ & $\begin{array}{l}\text { Penelitian } \\
\text { deskriptif } \\
\text { dan analisa } \\
\text { data yang } \\
\text { digunakan } \\
\text { adalah } \\
\text { berupa } \\
\text { distribusi } \\
\text { frekuensi }\end{array}$ & $\begin{array}{l}\text { Peran } \\
\text { Keluarga } \\
\text { dalam } \\
\text { Pencegahan } \\
\text { Stroke pada } \\
\text { Pasien } \\
\text { Hipertensi di } \\
\text { Puskesmas } \\
\text { Bendo } \\
\text { Kecamatan } \\
\text { Pare } \\
\text { Kabupaten } \\
\text { Kediri }\end{array}$ & $\begin{array}{l}\text { Jurnal ILKES } \\
\text { (Jurnal Ilmu } \\
\text { Kesehatan) } \\
\text { Vol. 9 No. 1 } \\
\text { Juni 2018 } \\
\text { ISSN : 2087- } \\
1287\end{array}$ & $\begin{array}{l}\text { Peran keluarga dalam } \\
\text { pencegahan komplikasi } \\
\text { pada hipertensi masuk ke } \\
\text { dalam kategori cukup } \\
\text { sebesar }(58,5 \%) 24 .\end{array}$ \\
\hline 6. & $\begin{array}{l}\text { Atika } \\
\text { Khoiru } \\
\text { n Nisa, } \\
\text { Anita } \\
\text { Joeliant } \\
\text { ina, } \\
\text { Dwi } \\
\text { Adji } \\
\text { Noront } \\
\text { oko }\end{array}$ & $\begin{array}{l}45 \\
\text { respond } \\
\text { en }\end{array}$ & Deskriptif & $\begin{array}{l}\text { Kesadaran } \\
\text { Diri Pasien } \\
\text { Hipertensi } \\
\text { dalam } \\
\text { Pencegahan } \\
\text { Kejadian } \\
\text { Stroke di } \\
\text { Puskesmas } \\
\text { Tambakrejo } \\
\text { Surabaya }\end{array}$ & $\begin{array}{l}\text { Prosiding } \\
\text { seminar } \\
\text { nasional } \\
\text { kesehatan } \\
2019 \\
\text { ISSN: 2684- } \\
9518\end{array}$ & $\begin{array}{l}\text { Pengontrolan diri penderita } \\
\text { hipertensi dalam } \\
\text { pencegahan stroke negatif } \\
\text { sebesar }(55,56 \%) 25 \text { yang } \\
\text { artinyaramana kemampuan } \\
\text { penderita hipertensi dalam } \\
\text { mengontrol hipertensi } \\
\text { masih rendah. }\end{array}$ \\
\hline 7. & $\begin{array}{l}\text { Rosa } \\
\text { Amelia, } \\
\text { Indah } \\
\text { Kurnia } \\
\text { wati }\end{array}$ & $\begin{array}{l}93 \\
\text { orang }\end{array}$ & $\begin{array}{l}\text { Cross } \\
\text { sectional } \\
\text { dengan uji } \\
\text { chi square. }\end{array}$ & $\begin{array}{l}\text { Hubungan } \\
\text { Dukungan } \\
\text { Keluarga } \\
\text { terhadap } \\
\text { Kepatuhan } \\
\text { Diet } \\
\text { Hipertensi } \\
\text { pada } \\
\text { Penderita } \\
\text { Hipertensi di } \\
\text { Kelurahan } \\
\text { Tapos Depok }\end{array}$ & $\begin{array}{l}\text { JKSP } \text { Volume } \\
3 \text { Nomor } 1,14 \\
\text { Februari } 2020 \\
\text { ISSN 2615- } \\
6571, \quad \text { ISSN } \\
2615-6563\end{array}$ & $\begin{array}{l}\text { Hasil nilai } \mathrm{p}=0,001 \text {, yang } \\
\text { berarti ada hubungan } \\
\text { dukungan keluarga untuk } \\
\text { kepatuhan dengan diet } \\
\text { hipertensi pada pasien } \\
\text { hipertensi di Desa Tapos } \\
\text { Depok. Nilai yang } \\
\text { diperoleh OR = 5,704 yang } \\
\text { berarti responden yang } \\
\text { menerima dukungan } \\
\text { keluarga yang baik akan } \\
\text { lebih mudah mematuhi diet } \\
\text { hipertensi mereka, } \\
\text { dibandingkan dengan } \\
\text { responden yang tidak } \\
\text { mendukung keluarga. }\end{array}$ \\
\hline 8. & $\begin{array}{l}\text { Yureya } \\
\text { Nita, } \\
\text { Dina }\end{array}$ & $\begin{array}{l}81 \\
\text { Orang }\end{array}$ & $\begin{array}{l}\text { Jenis } \\
\text { kuantitatif } \\
\text { dengan }\end{array}$ & $\begin{array}{l}\text { Hubungan } \\
\text { Dukungan } \\
\text { Keluarga }\end{array}$ & $\begin{array}{l}\text { Jurnal Ilmu } \\
\text { Kesehatan } \\
\text { VOL. } 6 \text { NO. } 1\end{array}$ & $\begin{array}{l}\text { Nilai } p \text {-value sebesar } 0,002 \\
(\mathrm{p}<0,05), \quad \text { yang berarti } \\
\text { adanya }\end{array}$ \\
\hline
\end{tabular}




\begin{tabular}{|c|c|c|c|c|c|c|}
\hline & Oktavia & & $\begin{array}{l}\text { pendekatan } \\
\text { studi } \\
\text { kolerasi }\end{array}$ & $\begin{array}{l}\text { dengan } \\
\text { Kepatuhan } \\
\text { Diet Pasien } \\
\text { Hipertensi di } \\
\text { Puskesmas } \\
\text { Payung } \\
\text { Sekaki } \\
\text { Pekanbaru } \\
\end{array}$ & JUNI 2018 & $\begin{array}{l}\text { dukungan keluarga } \\
\text { terhadap kepatuhan diet } \\
\text { pasien hipertensi. }\end{array}$ \\
\hline 9. & $\begin{array}{l}\text { Syifa } \\
\text { Muthm } \\
\text { ainnah }\end{array}$ & $\begin{array}{l}52 \\
\text { Respon } \\
\text { den }\end{array}$ & $\begin{array}{l}\text { Desain } \\
\text { penelitian } \\
\text { menggunak } \\
\text { an cross } \\
\text { sectional }\end{array}$ & $\begin{array}{l}\text { Hubungan } \\
\text { Dukungan } \\
\text { Keluarga } \\
\text { dengan } \\
\text { Kepatuhan } \\
\text { Minum Obat } \\
\text { pada Pasien } \\
\text { Hipertensi di } \\
\text { Rumah Sakit } \\
\text { Umum } \\
\text { Kecamatan } \\
\text { Cempaka } \\
\text { Putih }\end{array}$ & $\begin{array}{l}\text { Jurnal } \\
\text { Keperawatan } \\
\text { Medikal } \\
\text { Bedah, } \\
\text { Agustus } 2017\end{array}$ & $\begin{array}{l}\text { Nilai p value } 0,005 \text { dan } \\
\text { hasil analisis dengan nilai } \\
\text { OR = 4,492 yang berarti } \\
\text { dukungan keluarga yang } \\
\text { baik mempunyai peluang } \\
4,492 \text { kali untuk patuh } \\
\text { dalam minum obat. }\end{array}$ \\
\hline 10. & $\begin{array}{l}\text { Widi } \\
\text { Priharto } \\
\text { no, } \\
\text { Sulisty } \\
\text { o } \\
\text { Andar } \\
\text { moyo, } \\
\text { Laily } \\
\text { Isroin }\end{array}$ & $\begin{array}{l}38 \\
\text { Respon } \\
\text { den }\end{array}$ & $\begin{array}{l}\text { Cross } \\
\text { sectional }\end{array}$ & $\begin{array}{l}\text { Hubungan } \\
\text { Dukungan } \\
\text { Keluarga } \\
\text { dengan } \\
\text { Kepatuhan } \\
\text { Pemenuhan } \\
\text { Diet pada } \\
\text { Penderita } \\
\text { Hipertensi } \\
\text { Desa } \\
\text { Demangan, } \\
\text { Kecamatan } \\
\text { Siman, } \\
\text { Kabupaten } \\
\text { Ponorogo }\end{array}$ & $\begin{array}{l}\text { Jurnal Ilmiah } \\
\text { Mahasiswa } \\
\text { Universitas } \\
\text { Muhammadiya } \\
\text { h Ponorogo } \\
\text { Health } \\
\text { Sciences } \\
\text { Journal }\end{array}$ & $\begin{array}{l}\text { Nilai } p \text { value }=0,000 \text { yang } \\
\text { artinya lebih kecil dari } \alpha= \\
0,05 \text { yang berarti adanya } \\
\text { hubungan pada keeratan } \\
\text { hubungan dengan nilai } \\
\text { Contingency Coefficient = } \\
0,585 \text { dengan kategori } \\
\text { cukup }\end{array}$ \\
\hline 11. & $\begin{array}{l}\text { Exa } \\
\text { Puspita, } \\
\text { Eka } \\
\text { Oktavia } \\
\text { rini, } \\
\text { Yunita } \\
\text { Dyah } \\
\text { Puspita } \\
\text { Santik }\end{array}$ & $\begin{array}{l}84 \\
\text { Respon } \\
\text { den }\end{array}$ & $\begin{array}{l}\text { Penelitian } \\
\text { deskriptif } \\
\text { analitik } \\
\text { dengan } \\
\text { desain cross } \\
\text { sectional. }\end{array}$ & $\begin{array}{l}\text { Peran } \\
\text { Keluarga dan } \\
\text { Petugas } \\
\text { Kesehatan } \\
\text { dalam } \\
\text { Kepatuhan } \\
\text { Pengobatan } \\
\text { Penderita } \\
\text { Hipertensi di } \\
\text { Puskesmas } \\
\text { Gunungpati } \\
\text { Kota } \\
\text { Semarang }\end{array}$ & $\begin{array}{l}\text { J.Kesehatan } \\
\text { Masyarakat } \\
\text { Indonesia. }\end{array}$ & $\begin{array}{lr}\text { Responden yang tidak } \\
\text { patuh dalam menjalani } \\
\text { pengobatan } & \text { hipertensi } \\
\text { dengan } & \text { presentase } \\
\text { responden cowo lebih besar } \\
\text { dari perempuan } & \text { sebanyak } \\
53,6 \% \text {. } & \end{array}$ \\
\hline 12. & $\begin{array}{l}\text { Wachid } \\
\text { ah }\end{array}$ & $\begin{array}{l}95 \\
\text { Respon }\end{array}$ & $\begin{array}{l}\text { Penelitian } \\
\text { kuantitatif }\end{array}$ & $\begin{array}{l}\text { Family } \\
\text { Support on }\end{array}$ & $\begin{array}{l}\text { Jurnal Ners } \\
\text { Vol. } 14, \text { No. } 3\end{array}$ & $\begin{array}{l}\text { Nilai } \mathrm{p} \text { value } 0,001(<0,05 \\
\text { ) dengan nilai a yaitu } 0,082\end{array}$ \\
\hline
\end{tabular}




\begin{tabular}{|c|c|c|c|c|c|c|}
\hline & $\begin{array}{l}\text { Yuniart } \\
\text { ika and } \\
\text { Fauzan } \\
\text { Muham } \\
\text { mad }\end{array}$ & den & $\begin{array}{l}\text { dengan } \\
\text { persilangan } \\
\text { pendekatan } \\
\text { cross } \\
\text { sectional, } \\
\text { total } \\
\text { sampling, } \\
\text { kuesioner }\end{array}$ & $\begin{array}{l}\text { the Activities } \\
\text { of Elderly } \\
\text { Hypertension } \\
\text { Patients in } \\
\text { Elderly } \\
\text { Gymnastics } \\
\text { Activities }\end{array}$ & $\begin{array}{l}\text { Special Issue } \\
2019\end{array}$ & $\begin{array}{l}\text { yang artinya adanya } \\
\text { hubungan antara dukungan } \\
\text { keluarga dengan keaktifan } \\
\text { lansia dalam melakukan } \\
\text { senam lansia }\end{array}$ \\
\hline 13. & $\begin{array}{l}\text { Jiri } \\
\text { Widims } \\
\text { ky }\end{array}$ & $\begin{array}{l}107 \\
\text { Respon } \\
\text { den }\end{array}$ & $\begin{array}{l}\text { Studi } \\
\text { ACCORD } \\
\text { BP }\end{array}$ & $\begin{array}{l}\text { The Role of } \\
\text { Arterial } \\
\text { Hypertension } \\
\text { in the } \\
\text { Primary } \\
\text { Prevention of } \\
\text { Stroke }\end{array}$ & $\begin{array}{l}\text { Cor et vasa } 58 \\
(2015) \quad \text { e279- } \\
\text { e286 }\end{array}$ & $\begin{array}{l}\text { Penurunan tekanan darah } \\
\text { sistolik menjadi } \leq 120 \\
\text { mmHg berhubungan dalam } \\
\text { pencegahan stroke. }\end{array}$ \\
\hline 14. & $\begin{array}{l}\text { Iin } \\
\text { Kusum } \\
\text { awarda } \\
\text { na, } \\
\text { Didik } \\
\text { Tamto } \\
\text { m, } \\
\text { Sugiart } \\
\text { o }\end{array}$ & $\begin{array}{l}147 \\
\text { Lansia }\end{array}$ & $\begin{array}{l}\text { Jenis } \\
\text { penelitian } \\
\text { observasion } \\
\text { al analitik } \\
\text { dengan } \\
\text { desain cross } \\
\text { sectional. }\end{array}$ & $\begin{array}{l}\text { Relationship } \\
\text { between } \\
\text { Knowledge } \\
\text { and Family } \\
\text { Support } \\
\text { Regarding } \\
\text { Hypertension } \\
\text { with Blood } \\
\text { Pressure } \\
\text { Control in } \\
\text { Elderly }\end{array}$ & 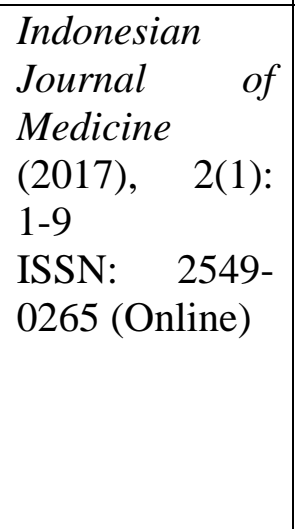 & $\begin{array}{l}\text { Nilai p value dukungan } \\
\text { keluarga yaitu } 0,046 \text { yang } \\
\text { artinya dukungan keluarga } \\
\text { meningkatkan lansia dalam } \\
\text { mengontrol tekanan } \\
\text { darahnya. }\end{array}$ \\
\hline 15. & $\begin{array}{l}\text { Ofoli } \\
\text { JN, } \\
\text { Dankya } \\
\text { u M, } \\
\text { Sule } \\
\text { JA, } \\
\text { Lass } \\
\text { DB }\end{array}$ & $\begin{array}{l}116 \\
\text { Respon } \\
\text { den }\end{array}$ & $\begin{array}{l}\text { Jenis } \\
\text { penelitian } \\
\text { cross } \\
\text { sectional }\end{array}$ & $\begin{array}{l}\text { Relationship } \\
\text { Between } \\
\text { Family And } \\
\text { Social } \\
\text { Support And } \\
\text { Adherence to } \\
\text { Treatment } \\
\text { Among } \\
\text { Outpatient } \\
\text { Hypertensive } \\
\text { s in an Urban } \\
\text { Hospital }\end{array}$ & $\begin{array}{l}\text { NJFP Vol } 8 \text { No } \\
1 \text { March, } 2017\end{array}$ & $\begin{array}{l}\text { Korelasi antara Variabel } \\
\text { dan Kepatuhan yaitu p } \\
\text { value } 0,013, \text { kategori } \\
\text { fungsi keluarga dengan } \\
\text { nilai p value } 0,001 \text { dan } \\
\text { dukungan sosial dengan } \\
\text { nilai p value } 0,005 \text {. }\end{array}$ \\
\hline 16. & $\begin{array}{l}\text { Ninuk } \\
\text { Dian } \\
\text { Kurnia } \\
\text { wati, } \\
\text { Erna } \\
\text { Dwi } \\
\text { Wahyu } \\
\text { ni, Yani } \\
\text { Arnold } \\
\text { us } \\
\text { Toulasi } \\
\text { k }\end{array}$ & $\begin{array}{l}200 \\
\text { Respon } \\
\text { den }\end{array}$ & $\begin{array}{l}\text { Desain } \\
\text { penelitian } \\
\text { ini adalah } \\
\text { deskriptif } \\
\text { korelasional } \\
\text { dengan } \\
\text { pendekatan } \\
\text { cross } \\
\text { sectional } \\
\text { Analisis } \\
\text { data } \\
\text { menggunak } \\
\text { an } \\
\text { Spearman }\end{array}$ & $\begin{array}{l}\text { Family } \\
\text { Support } \\
\text { Improves } \\
\text { Hypertensive } \\
\text { Patient Drug } \\
\text { Compliance }\end{array}$ & $\begin{array}{l}\text { Indian Journal } \\
\text { of Public } \\
\text { Health } \\
\text { Research \& } \\
\text { Development, } \\
\text { August 2019, } \\
\text { Vol.10, No. } 8 \\
\text { DOI Number: } \\
\text { 10.5958/0976- } \\
5506.2019 .022 \\
70.8\end{array}$ & $\begin{array}{l}\text { Ada hubungan antara } \\
\text { dukungan keluarga dan } \\
\text { kepatuhan minum obat } \\
\text { dengan nilai p value yaitu } \\
\text { 0,000, kepatuhan minum } \\
\text { obat dan tekanan darah } \\
\text { sistolik dengan nilai p } \\
\text { value 0,000 dan kepatuhan } \\
\text { minum obat dengan } \\
\text { tekanan darah 94iastolic } \\
\text { dengan nilai v value } 0,000 .\end{array}$ \\
\hline
\end{tabular}




\begin{tabular}{|c|c|c|c|c|c|c|}
\hline & & & Rho & & & \\
\hline 17. & $\begin{array}{l}\text { Devi } \\
\text { Widyan } \\
\text { ingrum, } \\
\text { Dwi } \\
\text { Retnani } \\
\text { ngsih, } \\
\text { Tamrin }\end{array}$ & $\begin{array}{l}137 \\
\text { Lansia }\end{array}$ & $\begin{array}{l}\text { Penelitian } \\
\text { kuantitatif } \\
\text { dengan } \\
\text { metode } \\
\text { deskriptif } \\
\text { korelasi } \\
\text { dengan } \\
\text { pendekatan } \\
\text { cross } \\
\text { sectional }\end{array}$ & $\begin{array}{l}\text { Hubungan } \\
\text { Dukungan } \\
\text { Keluarga } \\
\text { Dengan } \\
\text { Kepatuhan } \\
\text { Minum Obat } \\
\text { Pada Lansia } \\
\text { Penderita } \\
\text { Hipertensi }\end{array}$ & $\begin{array}{l}\text { Jurnal Ilmu } \\
\text { Keperawatan } \\
\text { Komunitas } \\
\text { Oktober 26, } \\
\text { 2019, Vol } 2 \\
\text { DOI Number } \\
\text { 10.32584/jikk. } \\
\text { v2i2.411 } \\
\text { ISBN: 2621- } \\
\text { 3001 }\end{array}$ & $\begin{array}{l}\text { Nilai p value yaitu } 0,000 \\
\text { dengan nilai koefisiensi } \\
\text { korelasi } 0,874 \text { yang berarti } \\
\text { adanya rabungan } \\
\text { dukungan keluarga dengan } \\
\text { kepatuhan minum obat } \\
\text { pada penderita hipertensi. }\end{array}$ \\
\hline
\end{tabular}

Tabel 1.3 menunjukkan terdapat 17 artikel yang menunjukkan adanya hubungan dukungan keluarga dan perilaku penderita hipertensi terhadap pencegahan stroke.

Menurut penelitian yang dilakukan oleh Ojo et al (2016) menyatakan bahwa responden yang rutin mengontrol tekanan darahnya sebesar $(46,4 \%)$ dan responden yang memiliki dukungan keluarga yang kuat sebesar (79,4\%). Mereka yang mendapat dukungan dari teman atau anggota keluarga memiliki kepatuhan yang lebih baik terhadap perawatan dari pada mereka yang tidak.

Menurut penelitian yang dilakukan oleh Aszrul \& Suswani (2017) menyatakan bahwa mayoritas responden mendapat dukungan keluarga dalam kategori baik sebesar (58\%) 29 dan yang tidak menerapkan upaya dalam meminimalisir serangan stroke sebesar $(66 \%)$ 33. Tingginya upaya penderita hipertensi dalam meminimalisir serangan stroke diperoleh dari dukungan keluarga yang baik seperti mengingatkan untuk minum obat, mengatur pola makan dan pola tidurnya penderita hipertensi maka sangat diperlukan dukungan dari keluarga untuk penderita hipertensi.

Dalam literature review ini penulis menggunakan analisa SWOT untuk menjelaskan kekuatan, kelemahan, peluang, serta ancaman dari keseluruhan artikel yang sudah dianalisa. a. Strenghths (Kekuatan):

Terdapat hubungan yang signifikan antara dukungan keluarga pada perilaku penderita hipertensi terhadap pencegahan stroke. Didapatkan data dukungan keluarga dalam kategori sedang hingga tinggi dalam mempengaruhi perilaku pencegahan stroke.

b. Weaknesses (Kelemahan):

Perilaku penderita hipertensi masih dalam kategori kurang hingga cukup sehingga dalam pencegahan stroke tidak maksimal.

c. Opportunities (Peluang):

Bisa dijadikan referensi bagi masyarakat yang memiliki keluarga dengan hipertensi agar lebih memperhatikan kesehatan penderita hipertensi karena hasil dari literatur yang didapat rata-rata menunjukkan dukungan keluarga dalam kategori sedang hingga tinggi sehingga perilaku dalam pencegahan stroke maksimal.

d. Threats (Ancaman atau Hambatan):

Perilaku penderita hipertensi yang masih rendah mengakibatkan terjadinya peningkatan komplikasi seperti stroke. Lamanya waktu dalam pengambilan data yaitu terlama 4 bulan dengan jumlah sampel terbanyak 360 responden. 


\section{KESIMPULAN}

Dari keseluruhan artikel penelitian didapatkan data responden yang mendapatkan dukungan keluarga masuk ke dalam kategori sedang hingga tinggi. Sedangkan responden yang mampu mengelola perilakunya dengan baik dalam pencegahan stroke pada penderita hipertensi masuk ke dalam kategori kurang hingga cukup. Tingginya upaya dalam mencegah terjadinya stroke dan tingginya perilaku dalam mengontrol kesehatan diperoleh dari dukungan keluarga yang baik. Sangat diperlukan kerja sama yang baik antara tenaga kesehatan, keluarga dengan penderita hipertensi dalam meningkatkan kesadaran diri penderita hipertensi untuk dapat melaksanakan perawatan diri dengan baik dalam mencegah komplikasi pada penderita hipertensi.

\section{UCAPAN TERIMAKASIH}

Terimakasih kepada kedua orang tua saya yang telah memberikan semangat dan doa. Terimakasih juga kepada Ns. Destiawan Eko Utomo, M. Kep., Sp. Kep. MB selaku dosen pembimbing yang telah memberi saran serta semangat kepada penulis.

\section{DAFTAR PUSTAKA}

AB, A., \& Andi Suswani. (2017). Dukungan Keluarga dengan Upaya Meminimalisir Serangan Stroke Penderita Hipertensi di Wilayah Kerja Puskesmas Bontonyeleng Kecamatan Gattareng. Jurnal Kesehatan PanritaHusada. https://doi.org/10.37362/jkph.v2i1.162

Amelia, R., \& Kurniawati, I. (2020). Hubungan Dukungan Keluarga terhadap Kepatuhan Diet Hipertensi pada penderita hipertensi di Kelurahan Tapos Depok. 3, 77-90.

Andri, J., Waluyo, A., Jumaiyah, W., \& Nastashia, D. (2018). Efektivitas Isometric Handgrip Exercise dan Slow Deep Breathing Exercise terhadap Perubahan Tekanan Darah pada Penderita Hipertensi. Jurnal Keperawatan Silampari. https://doi.org/10.31539/jks.v2i1.382

Asmiarti, D. (2018). Peran Keluarga dalam Pencegahan Stroke pada Pasien Hipertensi di Puskesmas Bendo Kecamatan Pare Kabupaten Kediri. Jurnal ILKES (Jurnal Ilmu Kesehatan), Vol. 9 No.

Bisnu, M., Kepel, B., \& Mulyadi, N. (2017). Hubungan Dukungan Keluarga dengan Derajat Hipertensi pada Pasien Hipertensi di Puskesmas Ranomuut Kota Manado. Jurnal Keperawatan UNSRAT.

Jumarni, Susanti, R., Sunarti, S. (2015). Hubungan Dukungan Keluarga dengan Upaya Pencegahan Stroke pada Penderita Hipertensi di Puskesmas Segiri Samarinda. Jurnal STIKes Muhammadiyah Samarinda.

Khoirun, A., Anita, N., \& Norontoko, D. A. (2019). Kesadaran Diri Pasien Hipertensi dalam Pencegahan Kejadian Stroke di Puskesmas Tambakrejo Surabaya. 263-266.

Muthmainnah, S. (2017). Hubungan Dukungan Keluarga dengan Kepatuhan Minum Obat pada Pasien Hipertensi di Rumah Sakit Umum Kecamatan Cempaka Putih. 1-9.

Nita, Y. (2018). Hubungan Dukungan Keluarga dengan Kepatuhan Diet Pasien Hipertensi di Puskesmas Payung Sekaki Pekanbaru Tahun 2017. Jurnal Ilmu Kesehatan.

Ofoli JN, Dankyau M, Sule JA, L. D. (2017). Relationship Between Family and Social Support and Adherence To. 8(1), 45-52. 
Ojo, O., Malomo, S., \& Sogunle, P. (2016). Blood pressure (BP) control and perceived family support in patients with essential hypertension seen at a primary care clinic in Western Nigeria. Journal of Family Medicine and Primary Care, 5(3), 569. https://doi.org/10.4103/2249-4863.197284

Prihartono, W., Andarmoyo, S., \& Isroin, L. (2019). Hubungan Dukungan Keluarga dengan Kepatuhan Pemenuhan Diet pada Penderita Hipertensi. Health Sciences Journal, 3(1), 1. https://doi.org/10.24269/hsj.v3i1.215

Puspita, E., Oktaviarini, E., Dyah, Y., \& Santik, P. (2017). Peran Keluarga dan Petugas Kesehatan dalam Kepatuhan Pengobatan Penderita Hipertensi di Puskesmas Gungpati Kota Semarang. Jurnal Kesehatan Masyarakat Indonesia,12(2),25-32. https://jurnal.unimus.ac.id/index.php/jkmi/article/download/3172/3056

Riskesdas. (2018). Hasil Utama Riskesdas 2018 Kesehatan. 200. http://www.depkes.go.id/resources/download/info-terkini/materi_rakorpop_2018/Hasil Riskesdas 2018.pdf

Widiandari, T. D., Widiani, E., \& Rosdiana, Y. (2018). Hubungan Dukungan Keluarga terhadap Motivasi Lansia dalam Pengelolaan Penyakit Hipertensi di Poli Interna RST Dr. Soepraoen Malang. Nursing News.

Widimský, J. (2016). The Role of Arterial Hypertension in the Primary Prevention of Stroke. Cor et Vasa, 58(2), e279-e286. https://doi.org/10.1016/j.crvasa.2015.11.005

Widyaningrum, D., Retnaningsih, D., \& Tamrin, T. (2019). Hubungan Dukungan Keluarga dengan Kepatuhan Minum Obat pada Lansia Penderita Hipertensi. Jurnal Ilmu Keperawatan Komunitas, 2(2), 21. https://doi.org/10.32584/jikk.v2i2.411

Yeni, F., Husna, M., \& Dachriyanus, D. (2016). Dukungan Keluarga Memengaruhi Kepatuhan Pasien Hipertensi. Jurnal Keperawatan Indonesia. https://doi.org/10.7454/jki.v19i3.471

Yuniartika, W., \& Muhammad, F. (2020). Family Support on the Activities of Elderly Hypertension Patients in Elderly Gymnastics Activities. Jurnal Ners, 14(3), 354. https://doi.org/10.20473/jn.v14i3.17213 